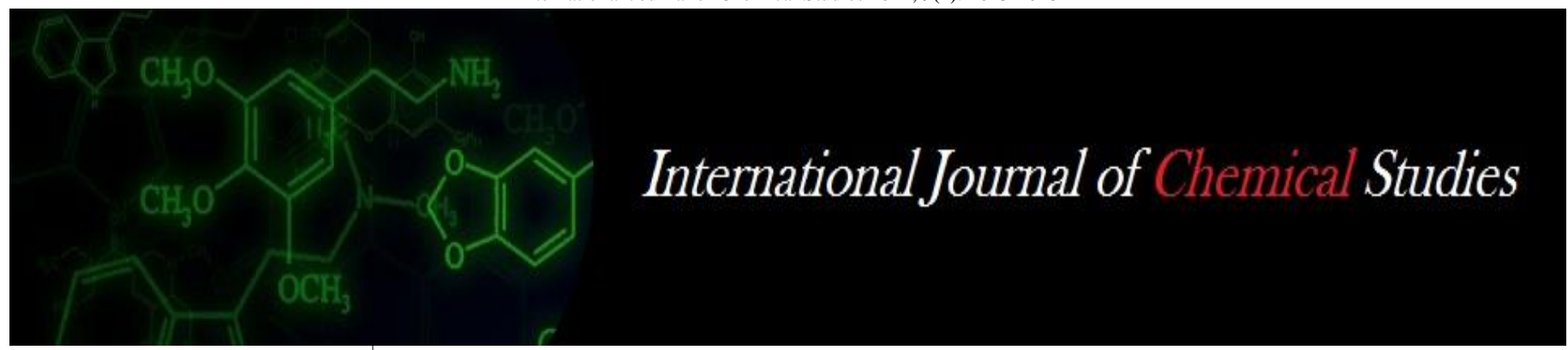

P-ISSN: 2349-8528

E-ISSN: 2321-4902

www.chemijournal.com

IJCS 2021; 9(1): 2043-2048

(C) 2021 IJCS

Received: 02-10-2020

Accepted: 12-11-2020

Deepak Lal

Department of Agrometeorology

(COA), Indira Gandhi Krishi

Vishwavidyalaya, Raipur,

Chhattisgarh, India

\section{GK Das}

Department of Agrometeorology

(COA), Indira Gandhi Krishi

Vishwavidyalaya, Raipur,

Chhattisgarh, India

\section{Pramod Kumar}

Department of Agrometeorology (COA), Indira Gandhi Krishi

Vishwavidyalaya, Raipur,

Chhattisgarh, India

\section{Yamlesh Nishad}

Department of Agrometeorology (COA), Indira Gandhi Krishi

Vishwavidyalaya, Raipur,

Chhattisgarh, India
Corresponding Author: Deepak Lal

Department of Agrometeorology (COA), Indira Gandhi Krishi

Vishwavidyalaya, Raipur,

Chhattisgarh, India

\section{Growth and development of mustard genotypes as influenced by different thermal environment under Chhattisgarh plain climatic conditions}

\author{
Deepak Lal, GK Das, Pramod Kumar and Yamlesh Nishad
}

DOI: https://doi.org/10.22271/chemi.2021.v9.i1ac.11523

\begin{abstract}
A field experiment was conducted Growth and development of mustard genotypes as influenced by different thermal environment under Chhattisgarh plain climatic conditions was carried out at the research farm, I.G.K.V., Raipur during rabi season of 2015-2016. The soil of experimental field was sandy loam in texture. The soil was neutral in reaction and had low phosphorus and medium nitrogen and potassium contents. The experiment was laid out in Factorial Randomized Block Design with three replications and two factors. First factor (thermal environment) viz., $\mathrm{D}_{1}-25.11 .2015, \mathrm{D}_{2}-05.12 .2015$ and $\mathrm{D}_{3}$-15.12.2015, second factor was varieties (3); PT-30 ( $\left.\mathrm{V}_{1}\right)$, PT-303 $\left(\mathrm{V}_{2}\right)$ and Pusa Mustard-26 ( $\left.\mathrm{V}_{3}\right)$. It was observed that the days required for attaining various phases from sowing to maturity stage varied considerably in different thermal environments. Early sowing on $25^{\text {th }}$ November took more days to mature as compared to delayed sowing i.e. $5^{\text {th }}$ and $15^{\text {th }}$ December. Growth and development was greatly influenced under different thermal environments. Significantly maximum growth was recorded from variety Pusa Mustard-26 in crop sown on $25^{\text {th }}$ November and minimum was recorded in PT-30 in crop sown on $15^{\text {th }}$ December.
\end{abstract}

Keywords: Growth and development, mustard crop, growing environments

\section{Introduction}

Rapeseed-mustard is most valuable edible oilseed crop all around the world after the soybean and palm in term of area and production. Rapeseed and mustard contain 40-45\% oil and 20$25 \%$ protein in seed. The oil is one of the most preferred cooking oils and is a good quality preservative, especially for the preparation of pickles. Its tender leaves are consumed as vegetables and seeds are used as condiments. Among the 53 rapeseed mustard growing countries Canada, China, India, Germany France, Australia, USA, etc. are the major growing countries. The worldwide annual production of rapeseed-mustard is 44.41 million tonnes of seed from an area of 27.24 million hectares. Canada is the leading producer followed by China and India (FAOSTAT, 2013) ${ }^{[4]}$.

Mustard is one of the most prominent oilseed crop next to groundnut in India. It contributes to a large extent in the national economy, and accounts for nearly $28.6 \%$ of the total oilseeds production in the country. Mustard is largely cultivated in Rajasthan, Gujarat, Haryana, Punjab, Odisha, West Bengal and Assam. In India mustard crop occupied an area of 64.54 Lakh ha with a production of 72.82 Lakh tones and productivity $1128 \mathrm{~kg} \mathrm{ha}^{-1}$. Rajasthan (29.27 Lakh ha and 37.64 Lakh tonnes) and Uttar Pradesh (10.26 Lakh ha and 11.29 Lakh tonnes) are the major producing states in the country (Anonymous, 2014-15) ${ }^{[3]}$. In Chhattisgarh, mustard is generally grown as rainfed crop after the rice and its sowing is dependent on harvesting of rice. Sowing of crop is often delayed due to growing of medium to late variety of rice by farmers. In Chhattisgarh mustard crop occupied an area of 0.67 Lakh ha with a production $0.54 \mathrm{Lakh}$ tonnes and an average productivity of $807 \mathrm{Kg} \mathrm{ha}^{-1}$. Sarguja is the leading district in the state with respect to area and production (Anonymous, 2012) ${ }^{[3]}$.

Weather and climate have major impact on production and productivity of agricultural crops. A certain climatic condition is required by mustard crop during its entire growing periods to obtain profitable production. Mustard is grown in tropical and temperate climate and is grown in winter season. Among all the weather parameters, temperature plays a significant role in better establishment, growth, development and finally the yield of crop. 
It requires about $18-25{ }^{\circ} \mathrm{C}$ temperature and low humidity for better crop growth. During seed germination and maturity stage slightly high temperature is required. Optimum temperature is $25{ }^{\circ} \mathrm{C}$. Rainfall, cloudiness and extreme cold and frost are harmful for the crop (Mukherjee et al., 2014) ${ }^{[10]}$.

\section{Material and Methods}

The field experiment was carried out during the rabi season of 2015-2016, at the research cum instructional farm of Indira Gandhi Krishi Vishwavidyalaya, Raipur. Raipur is located in south-eastern part of Chhattisgarh belongs to Chhattisgarh plain zone at latitudes, longitude and altitude of $21.16^{\circ} \mathrm{N}$, $81.36^{\circ} \mathrm{E}$ and $289.5 \mathrm{~m}$ above M.S.L. (Mean Sea Level) respectively. The climate of Raipur is sub-humid and often varies from moist sub-humid to semiarid. The mean annual rainfall is about $1250 \mathrm{~mm}$, out of which 85 per cent rainfall is received during June to September. It is characterized by low rainfall and moderately low temperature during rabi season (October to February). Mustard is mainly grown during rabi season. Seasonal changes prevailing during the growing period of crop play an important role in the crop growth, which ultimately influences the yield of the crop.

\section{Observations recorded}

\section{Plant population}

A quadrate of one $\mathrm{m}^{2}$ was thrown randomly and the number of plants within the quadrate was noted down and plant populations were recorded. The same procedure was followed in four places in each plot and the average number of plants $\mathrm{m}^{-2}$ was worked out. The plant population was recorded at 15 DAS.

\section{Plant height $(\mathrm{cm})$}

The height of plants were measured from the ground level to tip of the main shoot from five randomly selected plants from each plot at 15 days interval starting from 15 days after sowing (DAS) till maturity. These plants were also used to record observations on total dry matter and leaf area index (LAI). The mean height was worked out by dividing the summation by five.

\section{Dry matter production}

The total dry matter production was recorded at 15 days interval from 15 DAS up to harvest by selecting five plants randomly each time and average dry matter production plant ${ }^{-1}$ was worked out. This was multiplied by the average number of plants $\mathrm{m}^{-2}$ to obtain the dry matter production $\mathrm{m}^{-2}$.

\section{Leaf area index}

The leaf area at different growth stages was measured through leaf area meter. The plants uprooted for dry matter production were used to obtain leaf area. The average leaf area plant ${ }^{-1}$ was obtained and converted into unit area $\left(1 \mathrm{~m}^{2}\right)$ by multiplying average number of plants $\mathrm{m}^{-2}$. The leaf area index was computed as,

$$
\mathrm{LAI}=\frac{\text { Area of leaves in a square }(\mathrm{cm})}{\text { Land area }(\mathrm{cm})}
$$

\section{Crop growth rate (CGR)}

Crop growth rate denotes overall growth rate of the crop and is measured after the fixed period of time, irrespective of the previous growth rate. The value was calculated by using the following equation.

$$
\text { Crop growth rate }(\mathrm{CGR})=\frac{\mathrm{W}_{2}-\mathrm{W}_{1}}{\mathrm{t}_{2}-\mathrm{\tau}_{1}}\left(\mathrm{~g} \mathrm{~m}^{-2} \mathrm{day}^{-1}\right)
$$

\section{Where,}

$\mathrm{W}_{2}-\mathrm{W}_{1}$ is the difference in dry biomass at the time intervals of $\left(\mathrm{t}_{2}-\mathrm{t}_{1}\right)$.

\section{Results and Discussion \\ Growth parameters \\ 1. Plant population}

The effect of different treatments on plant population are presented in table 1 . The plant population per unit area under different thermal environments revealed that plant population was influenced significantly by different thermal environment. Significantly higher plant population $\left(\mathrm{m}^{-2}\right)$ was recorded in first thermal environments as compared to second and third thermal environments. The variation in plant population $\left(\mathrm{m}^{-2}\right)$ observed in different mustard varieties under different thermal environments might be due to low temperature during seed germination which influenced the germination. Similar finding was also reported by Manikrao, (2005) ${ }^{[8]}$ found variation in plant population in mustard varieties due to delayed sowing.

The data on plant population per unit area of different varieties grown under different thermal environments is shown in table 4.2. It can be seen from table 4.2 that plant population was significantly higher in variety Pusa Mustard26 as compared to varieties PT-30 and PT-303. Lowest plant population was observed from variety PT-30 which did not differ significantly from PT-30 and PT-303. This might be due to genetic makeup of different varieties and their response.

Table 1: Plant population $\left(\mathrm{m}^{-2}\right)$ of mustard varieties under different thermal environments

\begin{tabular}{|c|c|c|c|c|}
\hline \multirow{2}{*}{ Varieties } & \multicolumn{4}{|c|}{ Plant population $\left(\mathbf{m}^{-2}\right)$} \\
\cline { 2 - 5 } & D1 & D2 & D3 & Mean \\
\hline PT-30 & 31.55 & 31.44 & 27.22 & 29.810 \\
\hline PT-303 & 31.88 & 31.88 & 28.00 & 30.329 \\
\hline Pusa Mustard-26 & 32.88 & 32.55 & 29.11 & 31.513 \\
\hline Mean & 32.11 & 31.96 & 28.11 & 30.72 \\
\hline & D & V & D X V & \\
\hline S.Em \pm & 0.24 & 0.73 & 0.42 & \\
\hline CD & 0.24 & 0.73 & & \\
\hline CV & 2.38 & \multicolumn{3}{|l}{} \\
\hline
\end{tabular}

\section{Plant height}

The plant height of different mustard varieties grown under various growing environments was recorded at 15 days intervals from sowing to harvesting and are presented in table 2. It was observed that plant height of mustard increase at slow rate up to $25 \mathrm{DAS}$. Whereas, maximum rate of increase in plant height was observed between 40-55 DAS. Significant difference in plant height was observed for different varieties and thermal environments while their interaction was found non-significant in all growth stages (25 DAS, 40 DAS, 55 DAS, 70 DAS, 85 DAS and at maturity). Significantly maximum value of plant height was observed in crop sown on $25^{\text {th }}$ November as compared to $5^{\text {th }}$ December while lowest value of plant height was observed from crop sown on $15^{\text {th }}$ December in all the variety. This might be due to favorable environmental conditions in prevailed of $25^{\text {th }}$ November sown crop. Similar findings were also reported by Bala, et al., (2011) and Angrej et al., (2002) ${ }^{[2]}$. Among the varieties 
tested, significantly maximum plant height recorded in Pusa Mustard-26 (153.8 cm) followed by varieties PT-303 (128.43 $\mathrm{cm})$ and variety PT-30 $(128.02 \mathrm{~cm})$ at maturity.
Differences in plant height of different varieties may be due to different growth habits and their genetic makeup which helps to survive under this agro-climatic situation.

Table 2: Plant height $(\mathrm{cm})$ of mustard varieties under different thermal environments

\begin{tabular}{|c|c|c|c|c|c|c|c|}
\hline \multirow{2}{*}{ Variety } & \multicolumn{9}{|c|}{ Plant height (cm) } \\
\cline { 2 - 7 } & Sowing date & 25 DAS & 40 DAS & 55 DAS & 70 DAS & 85 DAS & At maturity \\
\hline & D1 & 16.89 & 57.09 & 94.81 & 114.13 & 123.21 & 128.02 \\
\hline PT-30 & D2 & 16.59 & 37.10 & 85.31 & 105.69 & 118.24 & 126.83 \\
\hline & D3 & 13.83 & 34.84 & 84.97 & 86.14 & 102.46 & 112.97 \\
\hline & D1 & 15.87 & 57.39 & 96.17 & 114.38 & 123.59 & 128.41 \\
\hline PT-303 & D2 & 16.47 & 36.62 & 92.54 & 110.06 & 118.69 & 123.95 \\
\hline & D3 & 14.08 & 36.59 & 88.70 & 91.48 & 108.45 & 119.01 \\
\hline & D1 & 19.43 & 69.94 & 122.87 & 139.74 & 147.83 & 153.64 \\
\hline Pusa Mustard-26 & D2 & 17.64 & 44.10 & 119.17 & 136.54 & 145.37 & 149.96 \\
\hline & D3 & 15.87 & 41.09 & 108.33 & 114.89 & 136.57 & 143.01 \\
\hline & D & 0.29 & 1.70 & 2.14 & 2.34 & 2.09 & 1.92 \\
\hline V & 0.29 & 1.70 & 2.14 & 2.34 & 2.09 & 1.92 \\
\hline S.Em & D X V & 0.53 & 2.96 & 3.71 & 4.02 & 3.63 & 3.32 \\
\hline CD & D & 0.87 & 3.97 & 6.42. & 6.96 & 6.28 & 5.76 \\
\hline V & 0.87 & 5.12 & 6.42 & 6.96 & 6.28 & 5.76 \\
\hline CV & D X V & NS & NS & NS & NS & NS & NS \\
\hline & & 5.34 & 11.13 & 6.48 & 6.19 & 5.03 & 4.38 \\
\hline
\end{tabular}

\section{Number of branches per plant}

The effect of different thermal environments and varieties on the number of branches plant ${ }^{-1}$ was recorded at harvest and are presented in table 3 .

In case of thermal environments, higher numbers of primary and secondary branches were found in crop sown on $25^{\text {th }}$ November followed by sowing on $5^{\text {th }}$ and $15^{\text {th }}$ December. Significant differences were also found in varieties under different thermal environments but interaction between date of sowing and varieties had shown non-significant difference.

Table 3: Number of branches plant ${ }^{-1}$ of different mustard genotypes under different thermal environments

\begin{tabular}{|c|c|c|c|}
\hline \multirow{2}{*}{ Varieties } & \multirow{2}{*}{ Sowing date } & \multicolumn{2}{|c|}{ Number of branches plant ${ }^{-1}$} \\
\hline & & Primary branches & Secondary branches \\
\hline \multirow[t]{3}{*}{ PT-30 } & D1 & 6.19 & 5.44 \\
\hline & D2 & 5.82 & 5.23 \\
\hline & D3 & 5.07 & 5.12 \\
\hline \multirow[t]{3}{*}{ PT-303 } & D1 & 6.37 & 5.72 \\
\hline & D2 & 5.83 & 5.41 \\
\hline & D3 & 5.03 & 5.10 \\
\hline \multirow[t]{3}{*}{ Pusa Mustard-26 } & D1 & 8.04 & 7.27 \\
\hline & D2 & 6.29 & 6.27 \\
\hline & D3 & 5.62 & 6.08 \\
\hline \multicolumn{4}{|c|}{ Primary branches } \\
\hline & $\mathrm{D}$ & $\mathrm{V}$ & $\mathrm{DXV}$ \\
\hline S.Em \pm & 0.14 & 0.14 & 0.25 \\
\hline $\mathrm{CD}$ & 0.43 & 0.43 & NS \\
\hline $\mathrm{CV}$ & 7.18 & & \\
\hline \multicolumn{4}{|c|}{ Secondary branches } \\
\hline & $\mathrm{D}$ & $\mathrm{V}$ & $\mathrm{DXV}$ \\
\hline S.Em & 0.11 & 0.11 & 0.19 \\
\hline $\mathrm{CD}$ & 0.34 & 0.34 & NS \\
\hline $\mathrm{CV}$ & 5.93 & & \\
\hline
\end{tabular}

The values of number of primary and secondary branches were observed highest in variety Pusa Mustard-26 followed by varieties PT-303 and PT-30 which might be due to the genetic makeup of the variety and effect of environmental factors. Similar results were also reported by Goyal, $(2006)^{[6]}$ and Yusaf et al., (2002).

\section{Leaf area index (LAI)}

Leaf area index (LAI) was measured and recorded at 15 days intervals from 25 DAS to 85 DAS are presented in table 4. The leaf area index (LAI) was varied in different varieties under different thermal environments. The leaf area index
(LAI) varied significantly within varieties and thermal environments at most of the stages during entire growing periods.

It was observed that the value of leaf area index increased rapidly in early stage of growth and reached maximum level at 55 DAS which is mainly due to maximum number of leaves developed during this period. After that these values decreased considerably. In all the varieties and thermal environment leaf area index was higher in first date of sowing followed by second and third sowing dates.

Among the varieties tested, maximum value of LAI was recorded at 55 DAS in variety Pusa Mustard-26 while lowest 
value of LAI was observed in variety PT-30 during all the growing environments. The extent of decline in leaf area index of mustard varieties under delayed sowing might be due to thermal stress and tolerance capacity of individual variety. Similar finding was also reported by Goyal, (2006) ${ }^{[6]}$ and Manikrao, (2005) ${ }^{[8]}$.

Table 4: Leaf area index of different mustard genotypes under different thermal environments

\begin{tabular}{|c|c|c|c|c|c|c|}
\hline \multirow{2}{*}{ Variety } & \multirow{2}{*}{ Sowing date } & \multicolumn{4}{|c|}{ Leaf area index } \\
\cline { 2 - 6 } & & $\mathbf{2 5}$ DAS & $\mathbf{4 0}$ DAS & 55 DAS & 70 DAS & 85 DAS \\
\hline & D1 & 0.60 & 1.34 & 2.12 & 1.26 & 0.88 \\
\hline PT-30 & D2 & 0.59 & 1.23 & 2.06 & 1.23 & 0.81 \\
\hline & D3 & 0.47 & 1.16 & 2.01 & 1.15 & 0.75 \\
\hline & D1 & 0.62 & 1.75 & 2.25 & 1.57 & 0.96 \\
\hline PT-303 & D2 & 0.53 & 1.21 & 2.18 & 1.47 & 0.92 \\
\hline & D3 & 0.49 & 1.08 & 2.08 & 1.14 & 0.86 \\
\hline Pusa Mustard- 26 & D1 & 0.89 & 2.44 & 2.76 & 2.53 & 1.21 \\
\hline & D2 & 0.75 & 2.12 & 2.49 & 2.25 & 1.08 \\
\hline D.Em+- & D & 0.61 & 2.09 & 2.35 & 2.02 & 0.91 \\
\hline CD & V & 0.21 & 0.047 & 0.035 & 0.063 & 0.023 \\
\hline & D X V & 0.036 & 0.047 & 0.035 & 0.063 & 0.023 \\
\hline & D & 0.062 & 0.081 & 0.061 & 0.108 & 0.039 \\
\hline & D X V & 0.062 & 0.14 & 0.105 & 0.188 & 0.068 \\
\hline & & NS & NS & 0.105 & 0.188 & 0.068 \\
\hline
\end{tabular}

\section{D1 25/11/2015, D2 05/12/2015, D3 15/12/2015}

\section{Dry matter production}

The total dry matter production $\left(\mathrm{g} \mathrm{m}^{-2}\right)$ recorded at an interval of 15 days from sowing to maturity for all the three varieties with respect to different thermal environments are presented in table 5.The data presented in table 5. Revealed that during different crop growth stages the trends of dry matter production was fluctuated due to different dates of sowing. The dry matter production $\left(\mathrm{g} \mathrm{m}^{-2}\right)$ at the time of sowing to harvest was significantly higher in first thermal environment than second and third thermal environments.

Table 5: Total dry matter production $\left(\mathrm{gm}^{-2}\right)$ of mustard varieties under different thermal environments

\begin{tabular}{|c|c|c|c|c|c|c|c|}
\hline \multirow{2}{*}{ Variety } & \multicolumn{7}{|c|}{ Dry matter accumulation $\left(\mathrm{gm}^{-2}\right)$} \\
\hline & Sowing date & 25 DAS & 40 DAS & 55 DAS & 70 DAS & 85 DAS & At maturity \\
\hline & D1 & 32.01 & 131.63 & 330.76 & 476.08 & 563.37 & 575.45 \\
\hline \multirow[t]{3}{*}{ PT-30 } & D2 & 31.87 & 124.60 & 316.24 & 448.16 & 546.34 & 558.05 \\
\hline & D3 & 29.61 & 119.64 & 296.19 & 432.51 & 509.84 & 515.77 \\
\hline & D1 & 33.34 & 136.22 & 337.61 & 476.91 & 572.55 & 588.81 \\
\hline \multirow[t]{3}{*}{ PT-303 } & D2 & 32.33 & 132.30 & 319.81 & 455.76 & 554.75 & 566.74 \\
\hline & D3 & 28.65 & 124.75 & 304.71 & 445.14 & 523.44 & 531.74 \\
\hline & D1 & 42.09 & 182.90 & 409.76 & 549.09 & 692.58 & 763.92 \\
\hline \multirow[t]{3}{*}{ Pusa Mustard-26 } & D2 & 40.68 & 163.59 & 368.64 & 516.67 & 628.72 & 683.50 \\
\hline & D3 & 37.26 & 151.70 & 355.23 & 495.64 & 601.30 & 644.34 \\
\hline & $\mathrm{D}$ & 0.53 & 2.06 & 4.05 & 5.50 & 6.24 & 7.71 \\
\hline \multirow[t]{2}{*}{ S.Em+- } & $\mathrm{V}$ & 0.53 & 2.06 & 4.05 & 5.50 & 6.24 & 7.71 \\
\hline & D X V & 0.91 & 3.56 & 7.01 & 9.52 & 10.80 & 13.35 \\
\hline \multirow[t]{3}{*}{$\mathrm{CD}$} & $\mathrm{D}$ & 1.58 & 6.17 & 12.13 & 16.48 & 18.70 & 23.35 \\
\hline & $\mathrm{V}$ & 1.58 & 6.17 & 12.13 & 16.48 & 18.70 & 23.35 \\
\hline & D X V & NS & NS & NS & NS & NS & NS \\
\hline $\mathrm{CV}$ & & 4.65 & 4.38 & 3.60 & 3.46 & 3.24 & 3.83 \\
\hline
\end{tabular}

The higher dry matter production under all the sowing dates was observed in Pusa Mustard-26 (763.92 $\mathrm{g} \mathrm{m}^{-2}$ ) as compared to other varieties, while lowest dry matter production was observed in PT-30 (515.75 $\left.\mathrm{g} \mathrm{m}^{-2}\right)$.

The different trend was observed in dry matter production of all three varieties tested. The dry matter production decreased considerably in all the varieties when sowing was delayed from $25^{\text {th }}$ November to $15^{\text {th }}$ December.

The biomass production is mainly governed by genetic potential of any variety grown under different thermal conditions. But extent of decrease in dry matter production under delayed sowing was due to thermal stress and tolerance capacity of particular variety. Similar findings were also reported by Goyal, (2006) ${ }^{[6]}$ and Alam et al., (2014) ${ }^{[1]}$ in which dry matter accumulation decreased with delayed sowing in all the varieties.

\section{Crop growth rate (CGR)}

The effect of treatments on crop growth rate of mustard varieties under different thermal environments is given in table 6. The data presented in table indicates that the crop growth rate increased slowly during initial stage of crop growth and after that it increased at higher rate during 40-55 DAS after that decreasing trends of crop growth rate was observed in all the varieties sown under different thermal environments.

The higher crop growth rate during 40-55 DAS was observed in crop sown on 25 November as compared to sowing on 
other thermal environments. During maturity stage, higher crop growth rate was observed in varieties Pusa Mustard-26 $\left(2.55 \mathrm{~g} \mathrm{~m}^{-2}\right.$ day $\left.^{-1}\right)$ while lowest crop growth rate was observed in PT-30 (1.48 $\left.\mathrm{g} \mathrm{m}^{-2} \mathrm{day}^{-1}\right)$. Higher crop growth rate was observed in variety Pusa Mustard-26 (15.12 $\mathrm{g} \mathrm{m}^{-2}$ day $\left.^{-1}\right)$ during 40-55 DAS under first thermal environment while lowest crop growth rate was observed in variety PT-30 (1.48 $\mathrm{g} \mathrm{m}^{-2}$ day $^{-1}$ ) during maturity stage.

Table 6: Crop growth rate $\left(\mathrm{g} \mathrm{m}^{-2} \mathrm{day}^{-1}\right)$ of mustard varieties under different thermal environments

\begin{tabular}{|c|c|c|c|c|c|c|c|}
\hline \multirow{2}{*}{ Varieties } & \multicolumn{7}{|c|}{ Crop growth rate $\left(\mathrm{g} \mathrm{m}^{-2}\right.$ day $\left.^{-1}\right)$} \\
\hline & Date of sowing & 0-25 DAS & 25-40 DAS & 40-55 DAS & 55-70 DAS & 70-85 DAS & 85-Maturity \\
\hline & D1 & 1.28 & 6.64 & 13.28 & 9.69 & 5.82 & 1.73 \\
\hline \multirow[t]{3}{*}{ PT-30 } & D2 & 1.31 & 6.12 & 12.78 & 8.79 & 6.54 & 1.95 \\
\hline & D3 & 1.24 & 5.90 & 11.77 & 9.09 & 5.16 & 1.48 \\
\hline & D1 & 1.33 & 6.86 & 13.43 & 9.29 & 6.38 & 1.81 \\
\hline \multirow[t]{3}{*}{ PT-303 } & D2 & 1.29 & 6.66 & 12.50 & 9.06 & 6.60 & 2.00 \\
\hline & D3 & 1.15 & 6.41 & 12.00 & 9.36 & 5.22 & 1.66 \\
\hline & D1 & 1.68 & 9.39 & 15.12 & 10.77 & 8.09 & 2.55 \\
\hline \multirow[t]{2}{*}{ Pusa Mustard-26 } & D2 & 1.63 & 8.19 & 13.67 & 10.00 & 7.34 & 2.28 \\
\hline & D3 & 1.49 & 7.63 & 13.57 & 9.36 & 7.04 & 2.39 \\
\hline
\end{tabular}

Higher crop growth rate might be due to timely sowing resulted in proper growth and development of plant lead to high leaf area index which accumulated more dry matter at a faster rate in unit time. Similar result was also reported by Kashyap, (2008) ${ }^{[7]}$ who found that growth rate was higher when crop was sown earlier as compared to late sowing.

\section{Relative growth rate (RGR)}

The influence of different thermal environments on relative growth rate of three mustard varieties is shown in table 7 . Results revealed that higher value of relative growth rate was observed in initial stage of crop growth. Higher relative growth rate was observed at emergence stage in all varieties as compared to observations taken during 85 DAS to onwards.

Higher relative growth rate was observed with sowing on $25^{\text {th }}$ November as compared to $5^{\text {th }}$ and $15^{\text {th }}$ December. All the varieties exhibit similar trends in all the sowing dates. Among the varieties, highest RGR at emergence stage was observed in variety Pusa Mustard-26 $\left(0.150 \mathrm{~g} \mathrm{~g}^{-1}\right.$ day $\left.^{-1}\right)$ while lowest RGR was observed in variety PT-303 $\left(0.134 \mathrm{~g} \mathrm{~g}^{-1}\right.$ day $\left.^{-1}\right)$.

Table 7: Relative growth rate of mustard varieties under different thermal environments at 15 days intervals

\begin{tabular}{|c|c|c|c|c|c|c|c|}
\hline \multirow{2}{*}{ Varieties } & \multicolumn{7}{|c|}{ Relative crop growth rate $\mathbf{g ~ g}^{-\mathbf{1}} \mathbf{d a y}^{\mathbf{1}}$ ) } \\
\cline { 2 - 7 } & Date of sowing & $\mathbf{0 - 2 5}$ DAS & $\mathbf{2 5 - 4 0}$ DAS & 40-55 DAS & $\mathbf{5 5 - 7 0}$ DAS & 70-85 DAS & 85-at harvest \\
\hline & D1 & 0.139 & 0.094 & 0.061 & 0.024 & 0.011 & 0.003 \\
\hline PT-30 & D2 & 0.140 & 0.089 & 0.062 & 0.023 & 0.013 & 0.004 \\
\hline & D3 & 0.137 & 0.090 & 0.060 & 0.025 & 0.011 & 0.003 \\
\hline & D1 & 0.140 & 0.094 & 0.061 & 0.023 & 0.012 & 0.003 \\
\hline & D2 & 0.139 & 0.094 & 0.059 & 0.024 & 0.013 & 0.004 \\
\hline PT-303 & D3 & 0.134 & 0.098 & 0.060 & 0.025 & 0.011 & 0.003 \\
\hline Pusa Mustard-26 & D1 & 0.150 & 0.098 & 0.054 & 0.022 & 0.013 & 0.004 \\
\hline & D2 & 0.148 & 0.093 & 0.054 & 0.023 & 0.013 & 0.003 \\
\hline
\end{tabular}

Interaction effect was also found significant and variety PT30 recorded highest RGR at emergence stage with the crop sown on $5^{\text {th }}$ December followed by $25^{\text {th }}$ November and $15^{\text {th }}$ December whereas these values were higher at maturity stage under $5^{\text {th }}$ December while similar value of RGR was observed under $25^{\text {th }}$ November and $15^{\text {th }}$ December.

In variety PT-303 at emergence stage, higher value of RGR $\mathrm{g}$ $\mathrm{g}^{-1}$ day $^{-1}$ was observed under sowing on $25^{\text {th }}$ November as compared to $5^{\text {th }}$ December and $15^{\text {th }}$ December at maturity stage. Highest value of RGR was observed under $5^{\text {th }}$ December sowing as compared to $25^{\text {th }}$ November and $15^{\text {th }}$ December sowings.

In variety Pusa Mustard-26 higher value of RGR at emergence stage was observed under $25^{\text {th }}$ November sowing followed by $5^{\text {th }}$ and $15^{\text {th }}$ December sowing and at maturity stage similar highest value of RGR was observed under $25^{\text {th }}$ November and $15^{\text {th }}$ December sowing followed by $5^{\text {th }}$ December sowing. The relative growth rate varied among the varieties because of the different genetic makeup of these varieties and their interaction with environmental factors. Similar effect also reported by Kashyap, (2008) ${ }^{[7]}$.

\section{References}

1. Alam MDM, Begum F, Roy P. Yield and yield attributes of rapeseed-mustard (Brassica) genotypes grown under late sown condition. Bangladesh Journal of AgriculturalResearch 2014;39(2):311-336.

2. Angrej S, Dhingra KK, Jagroop S, Singh MP, Singh J, Singh A. Effect of sowing time and plant density on growth, yield and quality of Ethiopian mustard (Brassica carinata A. Br.). Journal of Research Punjab Agriculture University 2002;39(4):471-475.

3. Anonymous 2012. www.agridept.cg.gov.in.

4. Anonymous. FAOSTAT 2013. www.faostatate.com

5. Anonymous 2014-15. http://www.religareonline.com

6. Goyal KS, Das B, Singh R, Mohanty AK. Influence of the thermal environment on phenology, growth and development of mustard varieties. Journal of Soils and Crops 2006;16(2):283-290. 
7. Kashyap RK. Influence of thermal environment on phenology, growth, yield and development of mustard (Brassica juncea L.) varieties after rice fallow. M.Sc. Thesis IGKV, Raipur 2008.

8. Manikrao KA. Influence of radiation on growth, development and yield of mustard genotypes. MSc. (Ag) thesis. IGKV Raipur 2005, P33-77.

9. Miri Y, Bagheri H. Evaluation of planting date of agronomical traits of canola (Brassica napus). International Research Journal of Applied and Basic Sciences 2013;4(3):601-603.

10. Mukherjee A, Banerjee S, Mukherjee S, Samanta S, Chakraborty AJ. Agrometeorological requirements and management practices of rapeseed-mustard in Gangatic West Bengol, AICRP on Agrometeorology (Mohanpur Centre), Directorate of Research, BCKV, West Bengal, India 2014, P32.

11. Yousuf K. Influence of thermal environments on phenology growth and development of Brassica genotypes. M. Sc. (Ag) Thesis IGKV, Raipur 2005, P6468 . 